Western University Scholarship@Western

Aboriginal Policy Research Consortium International (APRCi)

2012

\title{
Aborigines, sport and suicide
}

Colin Tatz

Australian National University

Follow this and additional works at: https://ir.lib.uwo.ca/aprci

Part of the Leisure Studies Commons, Sociology of Culture Commons, and the Sports Studies Commons

\section{Citation of this paper:}

Tatz, Colin, "Aborigines, sport and suicide" (2012). Aboriginal Policy Research Consortium International (APRCi). 425.

https://ir.lib.uwo.ca/aprci/425 
This article was downloaded by: [University of Western Ontario]

On: 01 December 2012, At: 07:46

Publisher: Routledge

Informa Ltd Registered in England and Wales Registered Number: 1072954 Registered

office: Mortimer House, 37-41 Mortimer Street, London W1T 3J H, UK

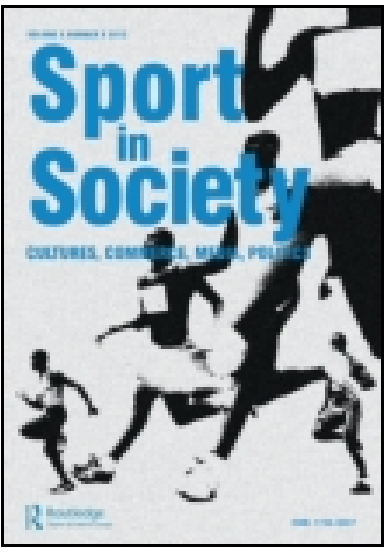

\section{Sport in Society: Cultures, Commerce, Media, Politics}

Publication details, including instructions for authors and subscription information:

http:// www. tandfonline.com/loi/fcss20

\section{Aborigines, sport and suicide}

Colin Tatz $^{a}$

a Politics and International Relations, Australian National

University, Canberra, Australia

Version of record first published: 03 Oct 2012.

To cite this article: Colin Tatz (2012): Aborigines, sport and suicide, Sport in Society: Cultures, Commerce, Media, Politics, 15:7, 922-935

To link to this article: http:// dx. doi.org/ 10.1080/ 17430437.2012.723352

PLEASE SCROLL DOWN FOR ARTICLE

Full terms and conditions of use: http://www.tandfonline.com/page/terms-and-conditions

This article may be used for research, teaching, and private study purposes. Any substantial or systematic reproduction, redistribution, reselling, loan, sub-licensing, systematic supply, or distribution in any form to anyone is expressly forbidden.

The publisher does not give any warranty express or implied or make any representation that the contents will be complete or accurate or up to date. The accuracy of any instructions, formulae, and drug doses should be independently verified with primary sources. The publisher shall not be liable for any loss, actions, claims, proceedings, demand, or costs or damages whatsoever or howsoever caused arising directly or indirectly in connection with or arising out of the use of this material. 


\title{
Aborigines, sport and suicide ${ }^{1}$
}

\author{
Colin Tatz \\ Politics and International Relations, Australian National University, Canberra, Australia
}

\begin{abstract}
It is surprising that a nation so dedicated to sport has ignored its role in trying to alleviate youth suicide. Involvement in sport has shown to deflect, even deter, juvenile delinquency. Similarly, there is evidence (and reason) enough to show a strong connection between sport and suicide among the young. Sport is a major element in contemporary Aboriginal life: it provides meaning, a sense of purpose and belonging; it is inclusive and embracing in a world where most Aboriginal youth feel alienated, disempowered, rejected and excluded.
\end{abstract}

\section{Expectations}

There have been few exalted or enlightened moments in Australian race relations since the white settlement began in 1788. For Aborigines, the consequences have been calamitous. Their contact history has been one of ignominy and the mood has been miserable for the most part. These experiences have had profound implications for the collective and the individual. In 1996, Chief Jean-Charles Piétacho of the Mingan First Nation addressed the Canadian Royal Commission on Aboriginal Peoples. His words ${ }^{2}$ are more than appropriate in a context where Australian Aboriginal youth commit suicide at a rate ${ }^{3}$ close to $40 \%$ greater than the national average:

Collective despair, or collective lack of hope, will lead us to collective suicide. This type of suicide can take many forms, foreshadowed by many possible signs: identity crisis, loss of pride, every kind of dependence, denial of our customs and traditions, degradation of our environment, weakening of our language, abandonment of our struggle for our Aboriginal rights, our autonomy and our culture, uncaring acceptance of violence, passive acknowledgement of lack of work and responsibilities, lack of respect for elders, envy of those who try to keep their heads up and who might succeed, and so on.

The expectations of improved race relations in Australia were greater after the racial and eugenic nightmare of the Holocaust became more widely known. The assimilationist ideas and (at times) integrationist policies of federal Minister for Territories, Paul Hasluck, from 1951 onwards seemed to embrace a modicum of racial equality, albeit in a contorted and distorted form of that inclusive ideal. But little of his philosophy or administrative prescriptions came to fruition either in the Northern Territory or in the states. ${ }^{4}$ The old protection-segregation statutes and programmes - established essentially between 1897 and 1911 - continued, but with new names: all Northern Territory Aborigines of 'full-blood' became 'wards', still incarcerated on remote settlements, missions and cattle stations, still unable to vote (until 1962), attend normal schools, drink, marry non-Aborigines without permission, have sex across the colour line, join trade unions, be paid social service benefits,

*Email: colintatz@gmail.com 
earn award wages and so on. Most of that kind of draconian control continued in Queensland until the mid-1980s. ${ }^{5}$

The 1967 national referendum purported to be, but in reality never was, an offer of a 'new deal' granting 'citizenship rights', a new era to be driven by [enlightened] federal rather than by [outmoded] state philosophies. ${ }^{6}$ The public's very positive response was quite beyond expectation. But the euphoria quickly subsided into a few legislative changes, producing little that was better, let alone new, in the day-to-day lives of people. Labor Party in federal office in 1972 began with a promise of radical change - which soon proved to be more of the same though in somewhat altered guise. The asylums of government-run settlements and Christian missions became 'communities', the earlier authoritarian administrative systems were dismantled, many of the old-style official guardians were replaced, and elected and funded councils came into being. But 'liberation' after nearly a century of protection and segregation was beyond the resources of under-trained, welfare-dependent, sequestered people faced with governmental demands for fiscal accountability and insistence on 'measurable outcomes' of 'policy goals'. From the 1950s, slogans came and went: assimilation, integration, selfdetermination, self-management, autonomy, consultation, reconciliation, 'practical reconciliation' and more recently, shared responsibility agreements. The words have changed but most realities have not. ${ }^{7}$

The legacies of history, geography and demography, the poverty, absence of economic resources, failure to provide elementary services and utilities, and the lack of will to affect major change are indelible. ${ }^{8}$ Yet each generation of policy-makers and administrators believes it can discover fire, or invent the wheel, each convinced it can start afresh; each, in turn, admits cynicism or defeat - and awaits the next cohort who will 'close the gap' on vital statistics, health, nutrition, education, housing, employment and training. As Pholi, Black and Richards ${ }^{9}$ point out, this is an approach that reduces Aboriginal Australians 'to a range of indicators of deficit, to be monitored and rectified towards government-set targets'. As each set of statistics on key social indicators such as life expectancy and infant mortality appears to improve, other indicators, such as deaths from non-natural causes, worsen. As more and more babies survive their first years, more and more young adults develop diabetes, heart, respiratory and renal diseases. As more education, training and intervention programmes are established, more and more youth are imprisoned.

In summary, long political, social and environmental contexts underlie and explain the current crises in Aboriginal life, a collective despair that very much includes the astounding levels and rates of youth suicide.

\section{Significant enquiries}

In the twentieth century alone, a remarkable number of public enquiries concerning Aborigines and Torres Strait Islanders were held under federal and state jurisdictions 118 in all. ${ }^{10}$ The great majority failed to produce change of any kind, but several did, including the enquiries that led to federal voting rights and land rights in the Northern Territory. Two other concerned life and death across the continent.

Paul Keating (Prime Minister from 1991 to 1996) seemed to have some sense of what was amiss and what was needed. His 10 December 1992 Redfern speech acknowledged the disasters, the murders, the land dispossession, the cultural destruction, the stolen children, the exploitation and the alcohol brought by the white society. His somewhat tardy preparedness in 1995 to establish an enquiry into the stolen generations, the children forcibly removed from their parents, was in retrospect quite monumental - at least insofar as it became witness records of those genocidal policies and practices. ${ }^{11}$ So too was the earlier appointment 
(in 1987) by Prime Minister Bob Hawke of a Royal Commission into Aboriginal deaths in custody (RCIADIC) - to enquire into the 'growing public concern' that these deaths 'were too common and public explanations were too evasive'. There were, indeed, rumours and accusations about 'assisted deaths' - of 'murder if not on behalf of the State at least by officers of the State'. ${ }^{12}$ Public agitation about conspiracies, corruption, murders and coverups in remote community police cells or in prisons generally led to a massive enquiry into 99 custodial Aboriginal deaths in the period from 1 January 1980 to 31 May $1989 .^{13}$

No common thread of abuse, neglect or racism was found but the Royal Commission found that 'their Aboriginality played a significant and in most cases dominant role in their being in custody and dying in custody'. ${ }^{14}$ The enormous shadow of that enquiry remains. Most state and territory jurisdictions now have laws and regulations governing the care of Aboriginal prisoners, with 'suicide watch' and a routine 'panic button', for the most part. No one wants a repetition of those very public and painful interrogations of bureaucrats, police and prison guards.

\section{Marx and Turnbull}

In 1989, the Criminology Research Council in Canberra funded my study into whether sports facilities and competition reduced the growing rates of delinquency in Aboriginal communities. The research took five years, with lengthy visits to 80 communities across the country and interviews with a total of 520 Aboriginal men and women, sports officials, policy and correctional service officers. This report, Aborigines: Sport, Violence and Survival, ${ }^{15}$ was the impetus for and the basis of my later analysis of Aboriginal youth suicide in New South Wales (NSW), the Australian Capital Territory and New Zealand. ${ }^{16}$ In brief, this sport and delinquency study coincided with the work of the RCIADIC and its investigators in the field. On my visits to communities, especially in South Australia, I began to hear far too many 'stories' about youth suicide and attempted suicide (or parasuicide). It did not take long to conclude that there was far more self-destruction and self-harm outside than inside custody, and that the Royal Commission was looking very narrowly at the visible tips of the ominous icebergs.

Suicide was a surprise. Perhaps it should not have been. In the 1970s, I had been reading the work of anthropologist Emanuel Marx on violent behaviour among North African youth in Israeli immigrant towns. ${ }^{17}$ There is, of course, a social context to this violent behaviour: it occurs more frequently among dislocated, transported or 'socially engineered' people from a different culture and geography. They are what anthropologist Colin Turnbull calls 'disordered societies' ${ }^{18}$ ). Marx wrote of 'appealing violence', a cry for help used by someone at the end of his/her tether, a person who feels unable to achieve a single social aim without the assistance of others. The person who cannot persuade his/her family to help, or to share his/her responsibilities, repeatedly attempts suicide as a desperate means of gaining family support. In summary, wrote Marx, this kind of appealing violence leads to harm to self or to others. At Raukkun in South Australia I witnessed a classic case: a young Aboriginal man had attacked his brother with an axe early in 1989. Admonished later by a local policeman's wife, he replied: 'Sorry, I'll never do it again: I'll only hurt myself' ${ }^{19}$

The much-vaunted human values of affection, social grouping for work or play, systems of law and religion, respect for the old, care of the young, are not inherent in humanity at all. Turnbull argues that such values are 'a luxury of ordered societies'. He was writing of the Ik, the Mountain People of Kenya and Uganda. Originally hunter-gatherers, they were forced to become farmers; forbidden to hunt, faced with poor land and drought, they have struggled for bare survival. 
Gloomy concepts emerge from gloomy pictures. Yet apart from the references that do not belong in our context - to the farming and the drought - if we substitute the calamity of incarceration on settlements, missions and pastoral properties, and the sudden withdrawal of white-imposed regimens (albeit harshly colonial and discriminatory), the description is astonishingly apt for many Aboriginal societies. Turnbull's breakdown of values and systems, of harm to self and to others, was what I had been seeing and reporting across Australia, ${ }^{20}$ and what was so elegantly yet painfully expressed by Chief Piétacho in 1996.

\section{Suicide in the literature}

Nevertheless, it was surprising because little Aboriginal suicide was found in any texts and records. In Aboriginal Suicide is Different, ${ }^{21}$ I described the literature research on Aboriginal suicide. Before the 1960s, there were no references to that phenomenon in the writings and records of missionaries and government officials, in anthropological and medical journals, fiction, memoirs, and in Aboriginal languages or artistic depictions. In the late 1960s, Malcolm Kidson and Ivor Jones ${ }^{22}$ found an absence of suicide in Western desert people and John Cawte ${ }^{23}$ saw 'nothing alarming' about Aboriginal suicide rates in Arnhem Land. In the 1970 s, Jones ${ }^{24}$ insisted that 'there was no incidence of suicide ... among tribal full-blood Aborigines'. In the 1980s, Harry Eastwell ${ }^{25}$ reported on 'the low risk of suicide among the Yolgnu of the Northern Territory'. Richard Kimber told the Royal Commission that there was no evidence of suicide in traditional communities; my late friend, anthropologist Lester Hiatt, told me he had never heard of a case of suicide in the Liverpool Region of the Northern Territory in his 40 years of fieldwork there - until the first report in 1998. In 1989 and 1993, Ernest Hunter's study of 25 suicides in the Kimberley showed that in the decade from 1959 to 1969, there was one suicide; between 1969 and 1979, three; and between 1979 and 1989, there were nineteen. ${ }^{26}$ Hunter and others stated ${ }^{27}$ that 'some three decades ago the suicide of an Indigenous Australian was a rare occurrence', but this is clearly no longer the case.

In 1981, an Honours student of mine at the University of New England, Christine McIlvanie (Stafford), examined in detail the case of Eddie Murray who died in a cell in the Wee Waa Watch-House, NSW, in June that year. In the course of this particularly vexed and suspicious case, McIlvanie ${ }^{28}$ had written to several police statistics units to see how common Aboriginal suicide was in custody. Sergeant 'K' of the Scientific Investigation Section of the NSW Police confirmed that in the period from 1971 to 1981 there had been one Aboriginal death in custody and five parasuicides in that state. Police figures for Queensland in this period appeared to have been nine suicides and eight parasuicides. For the Northern Territory, it is likely that there were five completed suicides in that decade. ${ }^{29}$ In summary, there appeared to be no undue alarm bells before 1980; suicide was something new in Aboriginal life, but it was a phenomenon that escalated to a rate that was among the highest in the world by the end of the century. By 2002, Aboriginal male suicide rates in the Territory had reached a staggering 66.3 per $100,000 .^{30}$

Something happened, or something 'snapped' as the century was coming to a conclusion. Elsewhere I have speculated on the causes of this eruption, of what looks like patterned, institutionalized and even ritualized self-death. ${ }^{31}$ The rates for those in the 15 to 24-year-old age cohort are staggering, with some 48 deaths per 100,000 Aboriginal people in my NSW study alone, compared with an Australia-wide rate of 20 per 100,000 for that age cohort. ${ }^{32}$ Hunter and Harvey ${ }^{33}$ report a Queensland mainstream young male rate of 14.5 per 100,000 and an Aboriginal rate of 23.6 for the same cohort, a figure they believe is much higher than is reported. Even more disturbing is the NSW rate (some 15 per 100,000) 
for those under 15, a statistic not usually reported, let alone discussed, in the literature on suicide rates. If explanations lie anywhere, they are to be found in the historical, political, legal and social environments in which this behaviour occurs, and not, as some writers ${ }^{34}$ assert, in the genes or brain chemistry of Aborigines.

\section{Sport and delinquency}

There is no incontestable proof that the presence of sporting facilities and competition reduces the level of violence against the person, or general criminal or delinquent behaviour. But, at a level just short of empirical proof, there is no doubt that sports facilities, participation and competition have had a marked impact on 'junior' crimes against property and on assaults. Among dozens of examples, Port Lincoln in South Australia is a striking case: in winter, during the football season, juvenile offending by Aborigines is virtually nil. Off-season, it soars. Neither the police nor the Aboriginal community doubt the relationship. Broome and Geraldton in Western Australia, Yuendumu, Barunga and Nguiu in the Northern Territory, Cherbourg and Woorabinda in Queensland, and Condobolin in NSW, among many others, bear out both the assertion and the relationship. There is some evidence that sport and outdoor recreation have drastically reduced the normally high number of juvenile offenders at Groote Eylandt in the Northern Territory. ${ }^{35}$

The 1994 report, while it raised the matter of suicide escalation in some detail, kept it close to the relationship between sport and delinquency, which at that time had become a major concern. It concluded that:

- sport plays a more significant role in the lives of Aborigines than in any other sector of Australian society;

- sport provides a centrality, a sense of loyalty and cohesion that has replaced some of the 'lost' structures in communities that so recently operated as Christian missions and government settlements;

- sport has become a vital force in the very survival of several communities now in danger of social disintegration;

- sport has helped reduce the considerable internalized violence - homicide, suicide, attempted suicide, rape, self-mutilation, serious assault - prevalent in some disordered communities;

- sport is a cheap enough option in the way it assists in reducing the second-highest cause of Aboriginal deaths, namely, from external and non-natural causes;

- sport has been effective in keeping youth out of serious (and mischievous) trouble during football and basketball seasons;

- sport has given several communities and regions an opportunity for some autonomy and sovereignty when they organize sport and culture carnivals - such as at Yuendumu and Barunga in the Northern Territory;

- sport takes place despite the absence of facilities, equipment, money for travel, discrimination against teams and/or access to regular competition;

- sport takes place in circumstances and environments that resemble Afghanistan in wartime and Somalia in drought time;

- sport is essential to counter the morale and moral despair of many Aborigines.

\section{Sport and adolescent suicide}

Harm and violence to property is not that far removed from harm to people. There is no concrete proof that they do belong in the same genre of behaviour. Nor is there ever likely to 
be such 'scientific' evidence. The best we can do is make reasonable and reasoned speculations, to work on what sociologist George Homans would call a high-order proposition - in this case, that just as sport appears to deflect delinquent behaviour of various kinds, activity will deflect, or postpone or even deter suicidal thoughts or their completion. I would go further and say that all the conclusions about sport and delinquency (mentioned above) apply in the case of sport and suicide. Several writers call sport as one of the protective factors against suicide, but the connection has attracted remarkably little attention among suicide or sports scholars, particularly in Australia - a curious omission in one of the world's foremost sports-oriented societies. Of note is the special supplement to the Australasian Psychiatry journal, ${ }^{36}$ which contains 20 original articles on aspects of Aboriginal emotional and physical well-being. Apart from a brief mention of Australian football by Brian McCoy, ${ }^{37}$ not one other author has mentioned, let alone considered, sport as part of that major agenda. (Ironically, there has been much more scholarly and journalistic interest in the number of sports stars who have taken their lives.)

There is some important evidence that there is a protective relationship. Sabo et al. ${ }^{38}$ conducted a study of a representative sample of 16,000 United States public and private high school students to see if there was a connection between athletic participation and suicide. There was a significant reduction in the odds of participants considering suicide among both males and females, as well as reduced odds of planning a suicide attempt among females in particular. With an admirable breadth of mind, the authors looked at classic sociological thought in the tradition of Emile Durkheim. ${ }^{39}$ Their proposition was that being enmeshed in a social network of teammates, coaches, health professionals, community and family, the athletic participants experienced less anomie and a much greater sense of social integration. Moreover, they concluded, 'a commitment to organized sports gives adolescent participants something to lose' ${ }^{40}$ The authors are acutely aware that sport promotes access and mobility for some groups, but that class, gender and race still preclude others, either historically or even contemporarily.

Chioqueta and Stiles ${ }^{41}$ studied 1102 male military recruits, looking for the cognitive factors, engagement in sport and suicide risk. They found that 'students actively involved in sports exhibited less hopelessness'. An even more compelling study by Babiss and Gangwisch $^{42}$ looked at sports participation as a protective factor against depression and suicidal ideation. Their findings are certainly encouraging. Sport, they state, typically boosts self-esteem, improves body image, increases social support and has an impact on substance abuse. As sports participation increases, the odds of suffering from depression decreases by $25 \%$, while the odds of having suicidal thoughts decreases by $12 \%$. The study took into account sex, age, race, ethnicity, public assistance and physical limitations.

Brown and Blanton ${ }^{43}$ evaluated the relationship between physical activity, sports participation and suicidal behaviour among 4728 college students in the United States. They found that sports participation was protective against suicidal behaviour: non-sporting men were 2.5 times more likely to report suicidal behaviour and non-sporting women, 1.67 times more likely to do so. The Tomori and Zalor ${ }^{44}$ study is somewhat less helpful, but remains another pointer. In a study of 4504 secondary students, aged 14-19, 458 self-reported their suicide attempts. In that group, attitudes to sport were negative and their sport involvement was nil or negligible. This suggests that sport had some importance in the lives of the nonattempters, though the authors say that they cannot claim that much about the relationship.

Curtis, Loy and Karnilowicz ${ }^{45}$ published a significant article on the 'dips' in suicide just before and during two important ceremonial sports events - the last days of the World Series baseball and the Super Bowl Sunday football event. Between 1972 and 1978, the suicide rates for the population were lower than normal on these specific days and higher 
thereafter; lower rates were also reported at the time of public holidays such as the Fourth of July and Thanksgiving. In essence, the study tested the Durkheimian propositions about the relationship between suicide and socially integrative activities - in this case, sport. [It would not be difficult to replicate this study at the time of the Barunga festival, the Yuendumu Games and the Nguiu football final in the Northern Territory and of the Aboriginal Rugby League Knockout weekend in NSW.]

Closer to home, New Zealand has experimented with sport as a deflector. In 1997, the Aranui Sports Academy was established as a way of stopping the drift of Maori and Polynesian boys out of school. ${ }^{46}$ Aranui High School switched from rugby league, at which they were champions, to rugby union to accommodate these young men. (The article does not explain why they switched codes.) In 1997, they beat St Bedes College in the final to win the schoolboys' championship. As the North and South magazine commented, such a predominantly Maori and Polynesian team victory would hardly arouse attention, but this was 'Christchurch, the most WASPish of all New Zealand cities and until this season, the final bastion of pre-Polynesian rugby'.

The organizers realized 'that one positive thing in many of these young people's lives was sport'. All 33 members of the Academy were properly enrolled in the school. The Academy's 'take (purpose) is about changing the kids' attitudes in order to make them more employable, not about winning on the sports field'. ${ }^{47}$ Students had to complete four years of senior schooling or have been away from school for a year. In addition to sports activities, classroom work was compulsory. The boys set the agenda, 'no one else'. Needless to say, there was a howl of protest in Christchurch at the Academy's victory, with allegations of Aranui bringing in professional rugby league adults to demolish amateur children in union. The Aranui project could be emulated in any number of NSW towns, where the residential divide between East side and West side (as in Christchurch) is as great.

David Denborough has been working with remote communities for many years. His recent book, Collective Narrative Practice: Responding to Individual Groups and Communities who have Experienced Trauma, has an innovative chapter entitled 'The Team of Life: Offering Young People a Sporting Chance'. ${ }^{48}$ Sport, he contends, is a realm within and through which life can develop richer meaning. It is indeed a glue that can hold a town or community together, a theme so brilliantly drawn about football in the depressed Texas town of Odessa by H.G. Bissinger in his 1990 Pulitzer Prize-winning book, Friday Night Lights: A Town, a Team, and a Dream. Sport not only provides lasting memories, but also enables 'young people who have experienced grave difficulties to speak differently about their lives'. ${ }^{49}$ The narrative therapy involves getting youth to ask what they like about a game, about creating a team of life, celebrating goals, tackling problems, avoiding obstacles and assisting others, whether in sport or beyond. Narrative therapy has developed as an effective process, especially in South Australia. ${ }^{50}$ It makes eminent sense to use metaphors and experiences that are known, are not threatening, give pleasure (albeit transiently), which do not involve what for many are the alien worlds of white coats, consulting rooms and heavy-duty pharmaceuticals. (Plato, in Book III of his Republic, written some 2391 years ago, told us that sport (gymnastics) was not just good for physical strength but for 'psychic harmony', and a way of avoiding physicians.)

$\mathrm{McCoy}^{51}$ has analysed the meaning of kanyirinpa among Aboriginal desert society people. It is a process of holding, a manner of looking after and nurturing young people. When boys mature, there is a shift from their care by women to older men who induct them into social meanings and behaviours. Despite enormous onslaughts on traditional culture, kanyirinpa has persisted in holding generations together, even of regenerating a society. McCoy has shown how young men have explored experiences that offer the possibility of 
kanyirinpa, including petrol sniffing, playing Australian football and location in prison. Without kanyirinpa, 'men grow up lost'. This is consistent with the Chandler and Lalonde ${ }^{52}$ study of British Columbia youth, where suicide is catastrophic in some Indian bands and almost non-existent in others. The construct of 'cultural continuity' is one where 'young persons undertake to construct and defend a sense of identity that allows them to survive despite dramatic change in their individual lives'. This, the authors claim, is the hedge (or protection) against suicide.

It is not unduly speculative to suggest that sport, especially the football codes, offer all young men in all cultures a mechanism for finding social meaning, 'a space of enjoyment and sociality', of not only being held or cradled, but also of being held together, in the McCoy or Chandler-Lalonde analyses, in a process of protection and of well-being. It is worth noting, and regretting, that much of suicidology tries to rest on 'evidence-based' empiricism. One of the giants of modern sociology, Pitirim Sorokin developed a remarkable theory of integralism, that is, that truth can be arrived at through the senses, reason and intuition, what anthropologists tend to call intuitive understanding or verstehen. ${ }^{53}$ Our present preoccupation with methodology, especially mathematical methodology, often diverts us from both reason and verstehen - tools essential in this domain of difficulty.

Elizabeth Parker et al. ${ }^{54}$ introduced a programme of restoring and teaching traditional Aboriginal games into the communities of Cherbourg and Stradbroke Islande in Queensland. The games are clearly culturally appropriate, holistic in several senses and have been found to be acceptable as well as supportive of community well-being. $\mathrm{Kral}^{55}$ reports a similar approach with a mix of scrabble, chess and ice hockey in Nunavut. Almost all the literature we have on strategies to combat youth suicide suggests or even insists that they must be culturally sensitive or appropriate. These initiatives bode well. But my point is that many modern, organized competitive sports - any of the football codes; athletic events; water sports; cycling; field sports such as cricket, baseball, softball and hockey; or indoor games such as basketball, netball, volleyball and darts - are integral to Aboriginal life, whatever their domains. They have seen these sporting activities live, or on television or film, and they have played one or another of its forms, even on the most bizarre of 'courts' and 'ovals'. They have long had teams and heroes they barrack for, identify with or have fantasies about. Modern, western sport is culturally appropriate; certainly, as we research and read the history of Aboriginal involvement in sport since the mid-nineteenth century, it has not been yet another colonial imposition, an institution they have had to 'endure' as some form of oppressive intrusion. Historically, it is an activity that they run to, literally, to avoid or escape another kind of oppression. Sport is there: it is not a strategy we have to invent, and then sell. The 'product' is available, but what is so often lacking is the ability to participate fully.

My colleague Daryl Adair has asked me a pertinent question. He wonders how sport participation has acted as a deterrent given that both Aboriginal and non-Aboriginal youth suicide rates have escalated in the past 40 years. If one assumes that participation rates in sport among young men in Australia were as reasonably similar in the 1940s and 1950s as they were, for example, in the 1960s and 1970s, did the sportive nature of Australian society suddenly erode for young males? Or did those most at risk from suicide became disenfranchized from sport in the 1960s and beyond? I don't have a satisfactory answer for non-Aboriginal youth, except to say that physical regimens for 10 years at school were clearly more imposed, even stringent, in the earlier era and that television, computer games, junk food, greater and easier access to drugs and alcohol, and the other ingredients of post1960s life have produced both languor, a sense of ennui, obesity and, as if it were a new phenomenon from outer space somewhere, 'pressure' or 'stress'. For Aboriginal youth, the loss of 'holding' by elders, of structure within the community, the withdrawal of colonial 
structures imposed from without and the realities of disadvantage, now viewable on all manner of screens, have produced dramatic changes in both individual and collective lives.

\section{A matter of access}

Because of their place in the political, legal, economic and social systems, Aborigines, Torres Strait and South Sea Islanders rarely get onto squash courts or championship golf courses, or into ski lodges. They do not hang-glide, play polo, sail yachts, ride bikes for Yamaha (apart from the amazing Chad Reed, now in the United States), or drive cars for Ferrari. On remote or rural reserves, where many Aborigines have lived, there was and is no grass, no facilities, coaches, nutritionists, physiotherapists, personal trainers, motivators, let alone floodlights or changing rooms. Scholarship money is rare and even then transfer to urban sports institutes down south pose a problem for most Aboriginal sports apprentices: homesickness. Most dislike travel from home territory, let alone relocating to another state.

Sporting success has not ended their harsh experiences back home. Much remains unchanged: short life-spans, gross ill-health, lack of housing and sanitation, massive unemployment, less than adequate education, social breakdown in many communities and a devastating youth suicide rate so indicative of people feeling a purposelessness about life. Yet sport is not a luxury or a leisure activity at the end of an arduous working week. For youth in many communities, it provides a sense of belonging and a feeling of coherence. It has ritual, a set of formal and informal rules, and it provides a real sense of what the esteemed sociologist Ferdinand Tönnies ${ }^{56}$ called gemeinschaft, a sense of belonging to an association that puts the group ahead of self and self-interest. Sport is more important to Aborigines than to any other segment of the Australian society. It not only lessens delinquency, in an era in which suicide rates are grossly abnormal, but it also gives youth a sense of belonging, something to stand for. It provides what the late Nazi camp survivor and psychiatrist Viktor Frankl called meaning and purpose, without which life is not worth living. Frankl ${ }^{57}$ identified three ways to discover meaning and purpose in life: (1) by creating a work or doing a deed; (2) by experiencing something or encountering someone; and (3) by enduring and taking an attitude to unavoidable suffering. Aborigines and Islanders have no shortage of condition (3), and sport, however transient, is effective in enabling conditions (1) and (2). There is enough evidence to show that even if sport does not actually prevent suicide, it clearly defers that action, often allowing a time-out period to reconsider life's chances. It also offers a chance for a period of wellness.

Wellness has been described as 'the healthy interconnection of mind, body, spirit [people], and the environment' - a perspective now at the forefront of the Inuit communities of Nunanvut in north Canada, a place of high youth suicide mortality. ${ }^{58}$ An essential ingredient of well-being is to be found in two letters of the alphabet: IQ, standing for Inuit Qaujimatuqangit, that is, traditional knowledge, including hunting, camping, tool- and clothes-making, in short, their cosmology and belief system. Community empowerment has come to mean a blend of Inuit epistemology and Euro-Canadian philosophies: as Kral puts it, 'the challenge stems, in part, from what kind of community is imagined and by whom'. 59 At this stage, only a small part of the holistic empowerment attack is about 'hockey skills development'. (Sport should, in my view, loom much larger in these strategies.) Unlike the stark terrain of places such as Baffin Island, the Australian landscape and climate offers much greater opportunity for programmes of mind and body. Yet we persist in seeing mind, body, spirit and terrain as distinct, discrete and disconnected domains.

Sport in one sense is ephemeral, here today, gone after the game. In another sense, it is an institutionalized behaviour, providing another game a week later and practice sessions in 
between. Off-season is a problem. Sport for non-players could be another difficulty, but only if one views sport narrowly as actual playing. McCoy has suggested to me that sport is not always inclusive and that those who do not or cannot play are outsiders. That is often true, but in reality all manner of activities are available for the non-athlete: working on the team newsletter or website, keeping records and scores, making rosettes and flags, engaging in publicity, becoming a touch judge or referee, organizing competitions and fund-raising - or, at the very least, attending matches as a fan. In a real sense, the sports organizers - whether trainers, coaches, managers - can as readily be, in McCoy's terms, the 'holders' of both players and their non-playing but involved supporters. In his book, Suicide: The Ultimate Rejection?, English academic Colin Pritchard ${ }^{60}$ posits that suicide is the culmination of unwantedness. My view is that one of the very essences of active involvement in sport is being wanted in some capacity; it is almost always embracing rather than rejectionist.

Sport is a powerful weapon in the fight against rampant diabetes; and many of today's illnesses, especially of the cardiac, renal and respiratory systems, are better controlled by physical regimens, including sporting competition, especially when they are associated with nutritional and dietary standards. For Aborigines, in many ways sport is survival: it provides a purpose in life, an activity of real meaning, a sense of coherence, a reason for being, a sense of power and empowerment, a space of enjoyment, of being and holding together and a feeling of autonomy, however brief. In the words of one Aboriginal Tiwi Islander, 'for the Tiwi people football means hope, it means pride and most of all it means life' ${ }^{61}$ Judd et al. ${ }^{62}$ ask whether space is a factor in rural suicide, a domain where Aboriginal suicide appears to be occurring at a greater rate than in urban contexts. Rural and remote community space is precisely where every facility for a reasonably normal life is lacking whether it be green vegetables, dialysis machines, regular medical and dental services, adequate water, electricity and sewage facilities, teachers who stay longer than half a year and, of course, even tolerable sports facilities, let alone regular competition. Places such as Kalumburu, Lombadina and Djarindjin in Western Australia; Wujal Wujal and Mornington Island in Queensland; Oenpelli, Kintore and Mt Liebig in the Northern Territory; Gingie Reserve in NSW and Yalata in South Australia have either nothing or salt pans to play on. I once wrote that if one considered the cost of playing sport as a tax, then remote and rural Aborigines pay the highest taxes in the continent for the very little they get.

We do not know why people commit suicide. As psychoanalyst James Hillman ${ }^{63}$ argues, we do not [and ca not] understand the soul of the suicide and we cannot get into the being of one who wants cessation of life. We, as a society, and sociology as a discipline, see suicide as negative, a wasteful exit from life, not as an entrance to death, a voluntary death in the words of Jean Améry, a Holocaust survivor who committed suicide and who wrote that 'people kill themselves out of a sense of dignity, preferring annihilation to the continuation of an existence lived in ignominy, desperate pain (physical or mental), or utter helplessness' ${ }^{64}$ For us, the young suicide is particularly 'unacceptable': he or she appears to engage in the reverse of Pritchard's ultimate rejection - it is not we who are rejecting the suicide but the suicide who is rejecting us - our love, family, faith, imagination, creativity, civilization. Sport may not prevent suicide, but it can alleviate suicidal ideas and actions, and even deflect or counter them.

\footnotetext{
Notes

${ }^{1}$ Based on a paper presented to Pathways to Reconciliation Summit, Amman, Jordan, 15 December 2009.

2 Quoted by Hunter and Harvey, 'Indigenous Suicide in Australia', 14.
} 
${ }^{3}$ Elliott-Farrelly. 'Australian Aboriginal Suicide', 2.

${ }^{4}$ Tatz, 'Aboriginal Administration'.

5 See McCorquodale, Aborigines and the Law, for a digest of such laws.

${ }^{6}$ Attwood and Markus, The 1967 Referendum.

7 Tatz, 'From Welfare to Treaty'.

8 Ibid.

9 Pholi, Black and Richards, 'Is "Close the Gap", 1.

${ }^{10}$ Horton, The Encyclopaedia of Aboriginal Australia, 1286-90.

${ }^{11}$ HREOC (Human Rights and Equal Opportunity Commission), Bringing Them Home; Tatz, Genocide in Australia.

12 RCIADIC I, 1.

13 RCIADIC I.

14 RCIADIC I, 1.

15 Tatz, 'Aborigines'.

16 See Tatz, Genocide in Australia and 'Aboriginal Suicide is Different'.

17 Marx, The Social Context of Violent Behavior, 2-6.

18 Turnbull, The Mountain People.

19 Tatz, 'Aborigines', 28.

${ }^{20}$ See Tatz, 'Pessimism in Australian Race Relations' and 'Aborigines'; Atkinson, 'Violence in Aboriginal Australia'.

${ }^{21}$ Tatz, 'Aboriginal Suicide is Different'.

22 Kidson and Jones, 'Psychiatric Disorders Among Aborigines'.

23 Cawte et al., 'Arafura, Aboriginal Town'.

24 Jones, 'Psychiatric Disorders Among Desert and Kimberley People', 17-20.

25 Eastwell, 'The Low Risk of Suicide Among the Yolgnu of the Northern Territory', 338.

${ }^{26}$ Hunter, 'Changing Mortality Patterns in the Kimberley Region of Western Australia 1957-86' and Aboriginal Health and History.

${ }^{27}$ Hunter et al., An Analysis of Suicide in Indigenous Communities of North Queensland, 91.

${ }^{28}$ McIlvanie, 'The Responsibility of People'.

29 Tatz, 'Aboriginal Suicide is Different', 20.

${ }^{30}$ Measey et al., 'Suicide in the Northern Territory', 317.

31 See works by Tatz, 'Aboriginal Violence'; 'Aboriginal Suicide is Different'; 'Aboriginal, Maori and Inuit Youth Suicide'.

32 De Leo and Evans, International Suicide Rates and Prevention Strategies, 25.

${ }^{33}$ Hunter and Harvey, 'Indigenous Suicide in Australia', 19.

${ }^{34}$ Such as Goldney, 'Is Aboriginal Suicide Different?'.

35 Owston, 'Declining Northern Territory Prison Populations'.

${ }^{36}$ McCoy, 'Suicide and Desert Men'.

37 McCoy, Holding Men.

${ }^{38}$ Sabo et al., 'High School Athletic Participation and Adolescent Suicide, 5-23.

39 Durkheim, Suicide.

40 Sabo et al., 'High School Athletic Participation and Adolescent Suicide, 5.

${ }^{41}$ Chioqueta and Stiles, 'Cognitive Factors, Engagement in Sport, and Suicide Risk'.

42 Babiss and Gangwisch, 'Sport Participation as a Protective Factor'.

43 Brown and Blanton, 'Physical Activity, Sports Participation, and Suicidal Behavior Among College Students'.

44 Tomori and Zalor, 'Sport and Physical Activity as Possible Protective Factors in Relation to Adolescent Suicide Attempts'.

45 Curtis, Loy and Karnilowicz, 'A Comparison of Suicide-Dip Effects', 1-14.

${ }^{46}$ North and South, 'East Side Story'.

47 Ibid., 1-2.

48 Denborough, Collective Narrative Practice.

49 Bissinger, Friday Night Lights.

50 Hunter and Milroy, 'Aboriginal and Torres Strait Islander Suicide in Context', 151.

${ }^{51}$ McCoy, 'Suicide and Desert Men' and Holding Men.

${ }^{52}$ Chandler and Lalonde, 'Cultural Continuity as a Hedge Against Suicide', 191.

53 Sorokin, The Crisis of Our Age.

54 Parker et al., 'Our Games our Health'. 
${ }^{55} \mathrm{Kral}$, 'Transforming Communities'.

56 Tönnies, Community and Society.

57 Frankl, Man's Search for Meaning, 133.

58 Kral, 'Transforming Communities'.

59 Ibid., 256-8.

${ }^{60}$ Pritchard, Suicide.

${ }^{61}$ Moodie, Tiwi Football Yiloga, 105.

62 Judd et al., 'Rural Suicide'.

${ }^{63}$ Hillman, Suicide and the Soul.

${ }^{64}$ Améry, On Suicide, xviii.

\section{References}

Améry, J. On Suicide: A Discourse on Voluntary Death. Bloomington, IN: Indiana University Press, 1999.

Atkinson, J. 'Violence in Aboriginal Australia'. Draft paper for the National Committee on Violence, Canberra, 1988.

Attwood, B., and A. Markus. The 1967 Referendum: Race, Power and the Australian Constitution. Canberra: Aboriginal Studies Press, 2007.

Babiss, L., and J. Gangwisch. 'Sports Participation as a Protective Factor Against Depression and Suicidal Ideation in Adolescents as Mediated by Self-Esteem and Social Support'. Journal of Developmental and Behavioral Pediatrics 30, no. 5 (2009): 376-84.

Bissinger, H. G. Friday Night Lights: A Town, A Team, and A Dream. Boston, MA: Addison-Wesley, 1990.

Brown, D., and C. Blanton. 'Physical Activity, Sports Participation, and Suicidal Behavior Among College Students'. Medicine and Science in Sports and Exercise 34 (2002): 1087-96.

Cawte, J., Baglin, D., Bianchi, G., McElwain, D. Money, J. and Nurcombe, B. 'Arafura, Aboriginal Town: The Medico-Sociological Expedition to Arnhem Land in 1968'. Unpublished typescript (restricted use), call number MS 483, Canberra, AIATSIS 1968.

Chandler, M., and C. Lalonde. 'Cultural Continuity as a Hedge Against Suicide'. Transcutural Psychiatry 35 (1998): 191-219.

Chioqueta, A., and T. Stiles. 'Cognitive Factors, Engagement in Sport, and Suicide Risk'. Archives of Suicide Research 11, no. 4 (2007): 375-90.

Curtis, J., J. Loy, and W. Karnilowicz. 'A Comparison of Suicide-Dip Effects of Major Sports Events and Civil Holidays'. Sociology of Sport Journal 3, no. 1 (1986): 1-14.

De Leo, D., and R. Evans. International Suicide Rates and Prevention Strategies. Cambridge, MA: Hogrefe \& Huber, 2004.

Denborough, D. Collective Narrative Practice: Responding to Individuals, Groups and Communities Who Have Experienced Trauma. Adelaide: Dulwich Centre, 2008.

Durkheim, E. Suicide: A Study in Sociology. London: Routledge \& Kegan Paul, [1897] 1968.

Eastwell, H. 'The Low Risk of Suicide Among the Yolgnu of the Northern Territory: The Traditional Aboriginal Pattern'. Medical Journal of Australia 148, no. 7 (1988): 338-40.

Elliott-Farrelly, T. 'Australian Aboriginal Suicide: The Need for an Aboriginal Suicidology?' Australian E-Journal for the Advancement of Mental Health 3, no. 3 (2004): 2-8.

Frankl, V. Man's Search for Meaning. New York: Washington Square Press, 1994.

Goldney, R. 'Is Aboriginal Suicide Different? A Commentary on the Work of Colin Tatz'. Psychiatry, Psychology and the Law 9, no. 2 (2002): 257-60.

Hillman, J. Suicide and the Soul. Woodstock, CT: Spring Publications, 1997.

Horton, D. The Encyclopaedia of Aboriginal Australia: Aboriginal and Torres Strait Islander History, Society and Culture. 2 vols. Canberra: Aboriginal Studies Press, 1994.

HREOC (Human Rights and Equal Opportunity Commission). Bringing Them Home: Report of the National Inquiry into Separation of Aboriginal and Torres Strait Island Children From Their Families. Sydney: Human Rights and Equal Opportunity Commission, 1997.

Hunter, E., and D. Harvey. 'Indigenous Suicide in Australia, New Zealand, Canada and the United States'. Emergency Medicine 14 (2002): 14-23.

Hunter, E. 'Changing Mortality Patterns in the Kimberley Region of Western Australia 1957-86: The Impacts of Deaths from External Causes'. Aboriginal Health Information Bulletin 11 (May 1989): 27-32. 
Hunter, E. Aboriginal Health and History: Power and Prejudice in Remote Australia. Melbourne: Cambridge University Press, 1993.

Hunter, E., J. Reser, M. Baird, and P. Reser. An Analysis of Suicide in Indigenous Communities of North Queensland: The Historical, Cultural and Symbolic Landscape. Canberra: Commonwealth Department of Health and Ageing, 1999.

Hunter, E., and H. Milroy. 'Aboriginal and Torres Strait Islander Suicide in Context'. Archives of Suicide Research 10 (2006): 141-57.

Jones, I. 'Psychiatric Disorders Among Desert and Kimberley People'. Australian Institute of Aboriginal Studies Newsletter 3, no. 6 (1973): 17-20.

Judd, F., A. Cooper, C. Fraser, and D. Julian. 'Rural Suicide: People or Place Effects?' Australia and New Zealand Journal of Psychiatry 40 (2006): 208-16.

Kidson, M., and I. Jones. 'Psychiatric Disorders Among Aborigines of the Australian Western Desert'. Unpublished typescript, call number PMS 918, Canberra, AIATSIS 1968.

Kral, M. 'Transforming Communities: Suicide, Relatedness, and Reclamation Among Inuit of Nunavut, Canada'. Doctoral thesis, McGill University, Montreal 2009.

Marx, E. The Social Context of Violent Behaviour: A Social Study of an Israeli Immigrant Town. London: Routledge \& Kegan Paul, 1976.

McCorquodale, J. Aborigines and the Law: A Digest. Canberra: Aboriginal Studies Press, 1987.

McCoy, B. 'Suicide and Desert Men: The Power and Protection of Kanyirninpa (Holding)'. Australasian Psychiatry (supplement) 15, no. S1 (2007): 63-7.

McCoy, B. Holding Men: Kanyirninpa and the Health of Aboriginal Men. Canberra: Aboriginal Studies Press, 2008.

McIlvanie, C. (Stafford). 'The Responsibility of People'. BA Honours dissertation, Politics Department, University of New England, Armidale 1982.

Measey, M.L., S.Q. Li, R. Parker, and Z. Wang. 'Suicide in the Northern Territory, 1981-2002'. Medical Journal of Australia 185, no. 6 (2006): 315-9.

Moodie, D. Tiwi Football Yiloga. Singapore: F11 Productions, 2008.

North and South, 'East Side Story'. October (1997): 74-80.

Owston, D. 'Declining Northern Territory Prison Populations: How This was Brought About by Effective Community Based Programs'. In March 27-29 1990 Conference Proceedings, ed. H. Strang and S. Gerull. Canberra: Australian Institute of Criminology, 1991: 7-15.

Parker, E., B. Meikeljohn, C. Patterson, K. Edwards, C. Preece, P. Shuter, and T. Gould. 'Our Games Our Health: A Cultural Asset for Promoting Health in Communities'. Health Promotion Journal of Australia 17, no. 2 (2006): 103-8.

Pholi, K., D. Black, and C. Richards. 'Is "Close the Gap" a Useful Approach to Improving Health and Wellbeing of Indigenous Australians?' Australian Review of Public Affairs 9, no. 2 (2009): $1-13$.

Pritchard, C. Suicide: The Ultimate Rejection? A Psycho-Social Study. Berkshire: Open University Press (McGraw-Hill Education), 1995.

RCIADIC (Royal Commission into Aboriginal Deaths in Custody). Commissioner Elliott Johnston QC, National Report. 5 vols. Canberra: Australian Government, 1991.

Sabo, D., K. Miller, K. Merrill, J.M. Farrell, and G. Barnes. 'High School Athletic Participation and Adolescent Suicide'. International Review for the Sociology of Sport 40, no. 1 (2005): 5-23.

Sorokin, P. The Crisis of Our Age. New York: Dutton, 1941.

Tatz, C. 'Aboriginal Administration in the Northern Territory of Australia'. Doctoral dissertation, Australian National University 1964.

Tatz, C. 'Pessimism in Australian Race Relations'. In Case Studies on Human Rights and Fundamental Freedoms, ed. William A. Veenhoven, 445-70, Foundation for the Study of Plural Societies, Vol. 1. The Hague: Martinus Nijhoff, 1975.

Tatz, C. 'Aboriginal Violence: A Return to Pessimism'. Australian Journal of Social Issues 25, no. 4 (1990): 245-60.

Tatz, C. 'Aborigines: Sport, Violence and Survival'. CRC Project 18/1989, Criminology Research Council, Canberra, April 1994.

Tatz, C. Genocide in Australia. Research Discussion Paper No. 8. Canberra: Australian Institute of Aboriginal and Torres Strait Islander Studies, 1999.

Tatz, C. Aboriginal Suicide is Different: A Portrait of Life and Self-Destruction, 2nd ed. Canberra: Aboriginal Studies Press, 2005a. 
Tatz, C. 'Aboriginal, Maori and Inuit Youth Suicide: Avenues to Alleviation?' Australian Aboriginal Studies 2 (2004): 15-25.

Tatz, C. 'From Welfare to Treaty: Reviewing Fifty Years of Policy and Practice'. In The Power of Knowledge, the Resonance of Tradition, ed. G. Ward and A. Muckle. Electronic publication of Papers from the AIATSIS Indigenous Studies Conference, September 2001. http://www.aiatsis. gov.au/rsrch/conf2001/PAPERS/FullPublication.pdf, 2005b.

Tomori, M., and B. Zalor. 'Sport and Physical Activity as Possible Protective Factors in Relation to Adolescent Suicide Attempts'. International Journal of Sport Psychology 31, no. 3 (2000): 405-13.

Tönnies, F. Community and Society: Gemeinschaft und Gesellschaft, ed. Charles Loomis. East Lansing, MI: Michigan State University Press, 1957.

Turnbull, C. The Mountain People. New York: Simon \& Schuster, 1972. 